\title{
The Relationship Between FDI, Poverty Reduction and Environmental Sustainability in Tunisia
}

\author{
Marwa Lazreg ${ }^{1} \&$ Ezzeddine Zouari ${ }^{1}$ \\ ${ }^{1}$ Department of Economics, Faculty of Economic Sciences and Management of Sousse, University of Sousse, \\ Tunisia \\ Correspondence: Marwa Lazreg, Department of Economics, Faculty of Economic Sciences and Management of \\ Sousse, University of Sousse, Tunisia. E-mail: marwa.lazreg87@gmail.com
}

Received: May 17, 2018; Accepted: May 31, 2018; Published: June 7, 2018

\begin{abstract}
Our goal in this paper is the study of the impact of FDI on poverty and sustainable development in the case of Tunisia and during the study period from 1985 to 2015. In addition, we use the test unit root of cointegration test, the model error correction of FMOLS and Granger causality. In the case of Tunisia, we find that all variables are integrated of order 1 . Thus, we can use the cointegration test. Indeed, the result of the null hypothesis test of no cointegration was rejected at the $5 \%$ threshold, which explains the presence of a cointegration relationship between FDI, sustainable development and poverty. Finally, we present and interpreted the results of the estimated FMOLS model and Granger causality test to study the contribution of FDI to the poverty reduction and sustainable development in Tunisia. We find that the LIDE variable measuring foreign direct investment has a significant negative impact on the GINI index. We notice the $\mathrm{LCO} 2$ variable that measures the $\mathrm{CO} 2$ emissions has a negative and significant impact on poverty as measured by the poverty gap at $\$ 1.91$. We prove that direct foreign investments have a significant negative impact on $\mathrm{CO} 2$ emissions. We find that the LIDE variable measuring foreign direct investment has a significant negative impact on the GINI index. We notice the LCO2 variable that measures the $\mathrm{CO} 2$ emissions has a negative and significant impact on poverty as measured by the poverty gap at $\$ 1.91$. We prove that direct foreign investments have a significant negative impact on $\mathrm{CO} 2$ emissions. We found that the LIDE variable measuring foreign direct investment has a significant negative impact on the GINI index. We notice the $\mathrm{LCO} 2$ variable that measures the $\mathrm{CO} 2$ emissions has a negative and significant impact on poverty as measured by the poverty gap at $\$ 1.91$. We prove that direct foreign investments have a significant negative impact on $\mathrm{CO} 2$ emissions.
\end{abstract}

Keywords: IDE, CO2 emissions, poverty, cointegration, FMOLS

\section{Introduction}

Developing countries in Asia, Africa and Latin America consider increasing foreign direct investment (FDI) as a source of economic development, modernization, income growth, employment and therefore reduction poverty. This seems to be reflected in their economic policies currently being pursued, which explicitly aim to improve FDI attraction conditions and to maximize the benefits of the presence of FDI in the national economy.

Over the past two decades, these countries have implemented sweeping economic reforms, including liberalization of its foreign trade and investment regimes and their domestic markets, and the privatization of public enterprises.

Given appropriate policies of the host country and a basic level of development, the potential benefits of FDI are job creation, acquisition of new technologies and knowledge, the development of human capital through training employees to new companies, contribution to international trade integration, creating a more competitive business environment and local business development / national, flow of ideas and global best practice standards promoting international competitiveness and increased tax revenues by FDI.

All these forms of benefits should contribute to economic growth and a higher employment growth, which is the most important / most effective tool to improve human welfare and poverty reduction in the developing countries.

The number of empirical studies examining the impact of foreign direct investment (FDI) and financial development on economic growth has steadily grown since the emergence of endogenous growth theory. In the literature on the growth of FDI, empirical studies have so far shown mixed results on the positive contribution of FDI to economic growth (Balasubramanyam et al., 1996; Borensztein et al., 1998). 
Meanwhile, in the literature on financial development and growth, the empirical results were more conclusive; Most studies have shown that the development of the financial sector contributes positively to economic growth (Beck et al., 2000; King and Levine, 1993; Levine et al., 2000).

Our goal in this paper is the study of the impact of FDI on poverty and sustainable development in the case of Tunisia and during the study period from 1985 to 2015. In addition, we originated the presentation and analysis unit root test of cointegration test and correction model errors. In the case of Tunisia, we found that only LIDE variables LPIB, LFBC and LCH are non-stationary in level according to the test Augmented Dickey-Fuller but all variables are stationary in first difference according to this test. Thereafter, first difference, all variables are stationary according to the unit root test used. So, all variables are integrated of order 1 . Thus, we can use the cointegration test.

Indeed, the results of the null hypothesis test of no cointegration were rejected at the 5\% threshold, which explains the presence of a cointegration relationship between FDI, sustainable development and poverty. Finally, we present and interpreted the results of the estimated FMOLS model and Granger causality test to study the contribution of FDI to the poverty reduction and sustainable development in Tunisia.

We find that the LIDE variable measuring foreign direct investment has a significant negative impact on the GINI index. We notice the $\mathrm{LCO} 2$ variable that measures the $\mathrm{CO} 2$ emissions has a negative and significant impact on poverty as measured by the poverty gap at $\$ 1.91$.

We find the LGINI variable measuring poverty has a positive impact on $\mathrm{CO} 2$ emissions. We noticed that poverty measured by the poverty gap at $\$ 3.1$ a negative impact on $\mathrm{CO} 2$ emissions. We prove that the LIDE variable measuring foreign direct investment has a negative and significant impact on $\mathrm{CO} 2$ emissions. We find that the LIDE variable measuring foreign direct investment has a negative and significant impact on poverty as measured by the poverty gap at $\$ 3.1$.

The rest of the paper is organized as follows: In Section 2, we present a literature review. The third section summarizes the econometric methodology. Data are presented in Section 4. Section 5 was dedicated to the interpretation of results. The inference is made in section 6.

\section{Literature Review}

Gohou and Soumare (2012) analyze the impact of FDI in reducing poverty in Africa based on panel data for 52 countries for the period 1990-2007 and the dependent variables are the Human Development Index (HDI) and real GDP per capita. To estimate the model, the two authors used the technique 2SLS.

The results of Granger causality tests show that there is bidirectional causality between FDI and GDP per capita and a unidirectional causality of FDI in the HDI. Panel regressions show that FDI is significant and improves LIVE HDI and GDP per capita. FDI has an impact on the well-being significantly different between African regions, The authors concluded that foreign direct investment has a positive impact on reducing poverty in the countries of Central and Eastern Africa. The poorest countries have the most significant impact of FDI on poverty reduction than other rich countries.

Moreover, Fowowe and Shuaibu (2014) conduct an empirical investigation of the relationship between the flow of foreign direct investment (FDI) and poverty in a sample of 30 African countries. The analysis covers the period 1981-2011, which extends beyond the 1990-2007 sample used by Gohou and Soumare (2012) and adopts the method of GMM (generalized methods of times).

The results showed that the FDI inflows have contributed significantly to reducing poverty in African countries, In addition, the interaction of FDI with financial development has significantly reduced poverty. In the same study, and as applied for Gohou and Soumare (2012) and Fowowe and Shuaibu (2014), the positive impact of FDI on poverty reduction was considered high in poor countries where the incidence poverty is high.

Israel (2014) has also studied the impact of FDI on poverty reduction in Nigeria, using time series data between 1980 and 2009. FDI has had a positive impact on poverty reduction. This is in contrast with the results obtained by Akinmulegun (2012) and Ogunniyi and Igberi (2014) separate studies on the impact of FDI on poverty in Nigeria.

Soumare (2015) examines the relationship between FDI and welfare North Africa from 1990 to 2011, using the dynamic panel data regression. In the study, the HDI and GDP per capita were used as indicators for wellbeing. The analyzes confirm the highly significant relationship between FDI net inputs and improved well-being in North Africa, so they show a positive association between FDI and poverty reduction. 
Fauzel et al. (2015) examine the impact of foreign direct investment flows on poverty reduction in some subSaharan countries from 1990 to 2010 . They used actual poverty as a measure of poverty reduction; they found that FDI leads to poverty reduction.

Another set of studies found no causality between FDI and poverty. For example, Akinmulegun (2012) addresses the effect of FDI on welfare in Nigeria, using data covering a period from 1986 to 2009 and methodology of vector autoregression (VAR). FDI had an insignificant effect on well-being.

These results are according to a separate study by Ogunniyi and Igberi (2014) who study the impact of FDI on poverty reduction in Nigeria. The period covered by the study is 1980-2012 using the estimation method of ordinary least squares (OLS). They found that FDI has not a significant impact on reducing poverty in Nigeria.

Soumare and Gohou (2009) also study the impact of FDI on growth and on reducing poverty empirically using econometric models on panel data between African countries. They examined the contribution of FDI to the reduction of poverty in Africa and all possible differences on the FDI function to reduce poverty among the regions of Africa.

They refused to use the raw data variables such as GDP and FDI and choose to use the reports as net FDI flows over the gross capital formation. This way, they have sought to obtain more accurate and detailed results. They used also the human development index instead of using GDP only as a variable to obtain more precise results on welfare. In this study, they conclude that there is a causal link between FDI and log GDP per capita therefore, FDI can reduce poverty and increase well-being. On the other hand, they indicate that the relationship between FDI and welfare varies greatly between regions of Africa. For example, FDI affects welfare in Central Africa and East, despite its impact in the North and Southern Africa remains insignificant.

Umoh et al. (2012) try to verify empirically the proposition that there is a bidirectional relationship between FDI and economic growth in Nigeria between 1970 and 2008 by applying only and simultaneous equation systems (Single and simultaneous equation systems), this was checked.

This finding was consistent to the search Mpanju (2012) which also analyze the impact of FDI inflows on Tanzania in job creation for 1990-2008. The study adopted a case study design with a quantitative research approach, representing an econometric analysis using ordinary least squares (OLS). The results indicate that there is a strong positive relationship between variables, which means that FDI has a significant impact on the structure of employment opportunities.

In Nigeria, Salami and Oyewale (2013) study the relationship between FDI and employment for the period 19902012. The study used the technique for estimating ordinary least squares (OLS). The variables used for this study are the total rate of employment growth, the export rate, the import rates, exchange rates, inflation and FDI. The analysis found a significant link between FDI and employment in Nigeria

Similarly, Abor and Harvey (2008) treat the effect of FDI on job creation in Ghana. He provided an overview of the effect of FDI on employment from the perspective of the receiving country. Simultaneous panel regression model was used to estimate the effect of FDI on employment and wages.

The result of this study indicated that FDI has a statistically significant and positive effect on employment levels in Ghana but has an insignificant effect on wages. They estimated that FDI can significantly enhance national efforts in creating more jobs in the economy.

The result showed that FDI affect employment quantitatively but not necessarily qualitatively. The study identified other factors, including; productivity, wages, sub-sector and location have not had much influence on wages in Ghana.

\section{Empirical Methodology}

Our goal in this paper is to study the impact of FDI on poverty and sustainable development in the case of Tunisia and during the study period between 1985 and 2015.

In our paper, we will use the model developed by Im and McLaren (2015) to study the impact of FDI on poverty in the countries of North Africa. The model used was as follows:

$$
P O V=f(I D E, V)
$$

Where; POV measure the poverty for each country, FDI measure foreign direct investment and V represents a vector of control variables. Thus, the control variables, the growth rate of gross domestic product (GDP), youth literacy rate (TAJ), financial development measured by domestic credit to the private sector (DF), the urban 
population (PU ), government spending (DEP) Market capitalization of listed companies (CBEC), the consumption or use of energy (EU), the inflation rate (INF), energy use renouvlable (CER), the gross capital formation (BCF) and the unemployment rate $(\mathrm{CH})$.

Note that poverty is measured by three indicators:

The GINI index.

The poverty gap at $\$ 1.91$.

The poverty gap of $\$ 3.1$.

FDI is measured by the level of FDI to GDP ratio for Tunisia.

The data used in this paper are annual frequency for all variables. These data come from the World Bank database and the International Monetary Fund for the period from 1985 to 2015. The choice of time series is based on one dimension is time (a period of 31 years for a single country is Tunisia.

\section{Data}

In this section we will try to make a descriptive analysis of the different results for the study the impact of FDI on poverty and sustainable development in the case of Tunisia. First, let's define the type of estimate is a regression in time series. Our choice is justified by the presence of only one dimension in the data used; this is the dimension of time (a period of 31 years) for a single country.

All of the descriptive statistics of the variables used in this paper are summarized in Table 1.

According to the results of Table 1, we found that the $\mathrm{LCO} 2$ variable, which expresses logarithm of $\mathrm{CO} 2$ emissions, can reach a maximum value of 10.19404 . As its minimum value is 9.371529 . Its risk is measured by the standard deviation is 0.270399 .

The LGINI variable, which measures the logarithm of the GINI index, can reach a maximum value of 3.771150 . While its minimum value is 3.578227 . Its risk is measured by the standard deviation is 0.066681 .

The variable \$ LPOV1_91, which measures the logarithm of the gap of poverty threshold of \$ 1.91 may reach a maximum value of 1.244155 . As its minimum value is -0.916291 . Its risk is measured by the standard deviation is 0.817983 .

The variable \$ LPOV3_1, which measures the logarithm of the poverty gap at $\$ 3.1$ threshold, can reach a maximum value of 2.449279 . As its minimum value is 0.741937 . Its risk is measured by the standard deviation is 0.629693 .

LIDE variable, which measures the logarithm of foreign direct investment, may reach a maximum value of 9.424248. As its minimum value is 0.600417 . Its risk is measured by the standard deviation is 1.783758 .

Both statistics of asymmetry (skewness) and kurtosis (kurtosis), we can conclude that all variables used in this paper are characterized by non-normal distribution. Then the asymmetry coefficients indicate that all variables are shifted to the left (negative sign of asymmetry coefficients) and is far from symmetrical except for LDEP variables LDF LFBC, LINF, LIDE and LTAJ which are oriented to the right (positive sign of asymmetry coefficients).

Also, the Kurtosis coefficient leptokurtic shows that for all variables used in this paper indicates the presence of a high peak or a large tail in their volatilities (leptokurtic the coefficients are greater than 1).

In addition, the positive sign of estimation coefficients of Jarque-Bera statistics indicates that we can reject the null hypothesis of the normal distribution of the variables used in our paper. In fact, the high value of the coefficients of the Jarque-Bera statistic reflects the series are not normally distributed at a level of 1 percent.

The results shown by the three skew statistics, kurtosis and Jarque-Bera suggest that all variables used in this paper are not normally distributed for the case of Tunisia and during the study period from 1985 to 2015.

Thus, we conducted a test of the correlation between the different variables used in the case of Tunisia and during the study period from 1985 to 2015. Table 2 summarizes the results for the Pearson correlation test.

In addition, the results showed that all coefficients between the explanatory variables do not exceed the tolerance limit (0.7), which does not cause problems in the estimation of the model. That is to say, we can integrate the different variables used in the same model. 
Table 1. Descriptive statistics

\begin{tabular}{|c|c|c|c|c|c|c|c|c|}
\hline variables & LCBEC & LCER & CHL & $\mathrm{LCO2}$ & LDEP & LDF & LFBC & LGINI \\
\hline Mean & 2.758591 & 2.652942 & 2.708440 & 9.841478 & 3.352433 & 4.145273 & 24.77924 & 3.682066 \\
\hline Median & 3.047404 & 2.661792 & 2.721295 & 9.899621 & 3.333792 & 4.119214 & 24.62026 & 3.694862 \\
\hline Maximum & 3.185539 & 2.776954 & 2.906901 & 10.19404 & 3.566570 & 4.336893 & 30.16257 & 3.771150 \\
\hline Minimum & 2.299159 & 2.568628 & 2.517696 & 9.371529 & 3.212160 & 3.940238 & 20.70988 & 3.578227 \\
\hline Std. Dev. & 0.393558 & 0.043064 & 0.108161 & 0.270399 & 0.115624 & 0.114830 & 2.218920 & 0.066681 \\
\hline skewness & -0.305758 & -0.237305 & -0.211769 & -0.338161 & 0.628275 & 0.259628 & 0.593701 & -0.368908 \\
\hline kurtosis & 1.128727 & 4.593033 & 2.021957 & 1.780516 & 2.334762 & 2.201199 & 3.170564 & 1.874858 \\
\hline Jarque-Bera & 59.06002 & 75.68887 & 84.67272 & 85.11713 & 96.11049 & 91.72457 & 98.58726 & 73.38324 \\
\hline Probability & 0.081839 & 0.167890 & 0.480160 & 0.284832 & 0.271030 & 0.556422 & 0.394805 & 0.310627 \\
\hline Sum & 85.51631 & 82.24121 & 83.96165 & 305.0858 & 103.9254 & 128.5035 & 768.1564 & 114.1440 \\
\hline Sum Sq. Dev. & 4.646642 & 0.055635 & 0.350966 & 2.193465 & 0.401067 & 0.395577 & 147.7081 & 0.133389 \\
\hline observations & 31 & 31 & 31 & 31 & 31 & 31 & 31 & 31 \\
\hline variables & LINF & LIDE & LPIB & \$ LPOV3_1 & \$ LPOV1_91 & LPU & LTAJ & LUE \\
\hline Mean & 4.721437 & 2.458078 & 2.421254 & 1.714848 & 0.251256 & 4.130709 & 4.475539 & 4.582495 \\
\hline Median & 4.490514 & 2.066680 & 2.667624 & 1.697449 & 0.019803 & 4.149968 & 4.416984 & 4.605834 \\
\hline Maximum & 8.225806 & 9.424248 & 5.695237 & 2.449279 & 1.244155 & 4.199380 & 4.577845 & 4.671519 \\
\hline Minimum & 1.983333 & 0.600417 & -4.502137 & 0.741937 & -0.916291 & 3.985998 & 4.416984 & 4.445511 \\
\hline Std. Dev. & 1.803147 & 1.783758 & 2.476342 & 0.629693 & 0.817983 & 0.063940 & 0.075328 & 0.065183 \\
\hline skewness & 0.435292 & 2.070721 & -0.997570 & -0.418324 & -0.211098 & -0.849307 & 0.496449 & -0.500923 \\
\hline kurtosis & 2.175180 & 8.694232 & 3.868922 & 1.679482 & 1.463566 & 2.530536 & 1.285346 & 1.870953 \\
\hline Jarque-Bera & 88.57733 & 64.03543 & 69.16824 & 91.56507 & 92.79384 & 90.11511 & 81.0938 & 79.42988 \\
\hline Probability & 0.395001 & 0.000000 & 0.046962 & 0.206335 & 0.194040 & 0.134559 & 0.079225 & 0.229582 \\
\hline Sum & 146.3645 & 76.20043 & 75.05889 & 53.16028 & 7.788938 & 128.0520 & 138.7417 & 142.0573 \\
\hline Sum Sq. Dev. & 97.54015 & 95.45375 & 183.9681 & 11.89541 & 20.07290 & 0.122649 & 0.170229 & 0.127463 \\
\hline observations & 31 & 31 & 31 & 31 & 31 & 31 & 31 & 31 \\
\hline
\end{tabular}

Table 2. The correlation matrix

\begin{tabular}{|c|c|c|c|c|c|c|c|c|}
\hline & LCBEC & LCER & CHL & $\mathrm{LCO2}$ & LDEP & LDF & LFBC & LGINI \\
\hline LCBEC & 1 & -0.322199716 & 0.326593121 & -0.415991935 & 0.746120465 & 0.382197086 & 0.196734383 & 0.004965653 \\
\hline LCER & -0.322199716 & 1 & 0.140323207 & -0.395190516 & -0.600997614 & -0.657109944 & 0.304835188 & 0.528807713 \\
\hline CHL & 0.326593121 & 0.140323207 & 1 & -0.602047169 & 0.068676267 & -0.187216321 & 0.203592967 & 0.619573429 \\
\hline $\mathrm{LCO2}$ & -0.415991935 & -0.395190516 & -0.602047169 & 1 & 0.055324836 & 0.419813358 & -0.365948272 & -0.668351255 \\
\hline LDEP & 0.646120465 & -0.600997614 & 0.068676267 & 0.055324836 & 1 & 0.591327082 & -0.192294478 & -0.419657296 \\
\hline LDF & 0.382197086 & -0.657109944 & -0.187216321 & 0.419813358 & 0.591327082 & 1 & 0.057966125 & -0.555037066 \\
\hline LFBC & 0.196734383 & 0.304835188 & 0.203592967 & -0.365948272 & -0.192294478 & 0.057966125 & 1 & 0.274523624 \\
\hline LGINI & 0.004965653 & 0.528807713 & 0.619573429 & -0.868351255 & -0.419657296 & -0.555037066 & 0.274523624 & 1 \\
\hline LINF & 0.640649679 & 0.043381446 & 0.312235672 & -0.613411545 & 0.542847496 & -0.108808039 & 0.135154309 & 0.278672077 \\
\hline LIDE & -0.44244559 & 0.041978444 & -0.657647075 & 0.476716293 & -0.298716252 & -0.008721661 & 0.057389391 & -0.397715388 \\
\hline LPIB & -0.383297183 & 0.065096941 & -0.339875035 & 0.167871578 & -0.393828118 & -0.326044993 & 0.139972482 & -0.061700663 \\
\hline \$ LPOV3_1 & 0.139196477 & 0.529039358 & 0.649374625 & -0.625889922 & -0.360634861 & -0.531269166 & 0.373771179 & 0.659469186 \\
\hline \$ LPOV1_91 & 0.232041678 & 0.494836969 & 0.66763199 & -0.645987995 & -0.275867841 & -0.484956813 & 0.382078515 & 0.627221089 \\
\hline LPU & -0.475919737 & -0.376287043 & -0.673197336 & 0.671654724 & -0.047289964 & 0.36444864 & -0.411080887 & -0.801749934 \\
\hline LTAJ & -0.102070373 & -0.409281088 & -0.682047824 & 0.622238299 & 0.395852134 & 0.427558173 & -0.390196877 & -0.688114401 \\
\hline \multirow[t]{2}{*}{ LUE } & 0.227166543 & 0.324215391 & 0.677896432 & -0.665828947 & -0.32092757 & -0.456905114 & 0.343107641 & 0.670679874 \\
\hline & LINF & LIDE & LPIB & \$ LPOV3_1 & \$ LPOV1_91 & LPU & LTAJ & LUE \\
\hline LCBEC & 0.640649679 & -0.44244559 & -0.383297183 & 0.139196477 & 0.232041678 & -0.475919737 & -0.102070373 & 0.227166543 \\
\hline LCER & 0.043381446 & 0.041978444 & 0.065096941 & 0.529039358 & 0.494836969 & -0.376287043 & -0.409281088 & 0.324215391 \\
\hline $\mathrm{CHL}$ & 0.312235672 & -0.657647075 & -0.339875035 & 0.649374625 & 0.66763199 & -0.673197336 & -0.682047824 & 0.677896432 \\
\hline $\mathrm{LCO} 2$ & -0.613411545 & 0.476716293 & 0.167871578 & -0.625889922 & -0.945987995 & 0.671654724 & 0.622238299 & -0.665828947 \\
\hline LDEP & 0.542847496 & -0.298716252 & -0.393828118 & -0.360634861 & -0.275867841 & -0.047289964 & 0.395852134 & -0.32092757 \\
\hline LDF & -0.108808039 & -0.008721661 & -0.326044993 & -0.531269166 & -0.484956813 & 0.36444864 & 0.427558173 & -0.456905114 \\
\hline LFBC & 0.135154309 & 0.057389391 & 0.139972482 & 0.373771179 & 0.382078515 & -0.411080887 & -0.390196877 & 0.343107641 \\
\hline LGINI & 0.278672077 & -0.397715388 & -0.061700663 & 0.659469186 & 0.927221089 & -0.601749934 & -0.688114401 & 0.670679874 \\
\hline
\end{tabular}




\begin{tabular}{lllllllll}
\hline LINF & 1 & -0.312575214 & -0.226995435 & 0.362941747 & 0.43032993 & -0.686437729 & -0.20011449 & 0.339811055 \\
LIDE & -0.312575214 & 1 & 0.288950392 & -0.394521943 & -0.418507846 & 0.467555412 & 0.38394208 & -0.401946081 \\
LPIB & -0.226995435 & 0.288950392 & 1 & -0.032364769 & -0.059327181 & 0.245195356 & 0.036646128 & -0.027248204 \\
\$ LPOV3_1 & 0.362941747 & -0.394521943 & -0.032364769 & 1 & 0.992283428 & -0.645121903 & -0.614023638 & 0.609347187 \\
\$ LPOV1_91 & 0.43032993 & -0.418507846 & -0.059327181 & 0.692283428 & 1 & -0.670687995 & -0.691230612 & 0.696084844 \\
LPU & -0.686437729 & 0.467555412 & 0.245195356 & -0.645121903 & -0.870687995 & 1 & 0.618570794 & -0.67111121 \\
LTAJ & -0.20011449 & 0.38394208 & 0.036646128 & -0.614023638 & -0.891230612 & 0.618570794 & 1 \\
LUE & 0.339811055 & -0.401946081 & -0.027248204 & 0.609347187 & 0.896084844 & -0.67111121 & -0.62445341 & 1 \\
\hline
\end{tabular}

\section{Empirical Analysis}

\subsection{The Unit Root Test}

A study of the causal relationship between FDI, sustainable development and poverty in the Tunsie first requires performing stationary tests to determine the order of integration of each series. The test results Augmented DickeyFuller applied to the series are shown in Table 3 for the case of Tunisia.

Thus, the acceptance or rejection of the null hypothesis of the test is based on the value of probability and test statistics indicated. These probabilities are compared with a 10\% threshold. If these probabilities are less than 10\%, then we reject the null hypothesis and if these probabilities are greater than $10 \%$, then we accept the null hypothesis.

In the case of Tunisia and according to Table 3, we observed that only LIDE variables LPIB, LFBC and CHL are non-stationary in level according to the test Augmented Dickey-Fuller but all variables are stationary in first difference according to this test.

Thereafter, first difference, all variables are stationary according to the unit root test used. So, all variables are integrated of order 1 . Thus, we can use the cointegration test.

Table 3. The unit root test

\begin{tabular}{lll}
\hline & \multicolumn{2}{l}{ Augmented Dickey-Fuller } \\
\hline & in level & In the first difference \\
\hline LGINI & -0.756063 & $-5.659891 *$ \\
\$ LPOV1_91 & -0.469796 & $-5.923327 *$ \\
\$ LPOV3_1 & -0.284486 & $-5.981466 *$ \\
LCO2 & -1.816191 & $-7.733605 *$ \\
LIDE & $-3.811822 *$ & $-9.307810 *$ \\
LINF & -2.373079 & $-9.371762 *$ \\
LPIB & $-5.499788 *$ & $-11.32135 *$ \\
LPU & -0.918562 & $-5.666020 *$ \\
LTAJ & -0.477248 & $-5.449179 *$ \\
LUE & -0.134862 & $-9.422873 *$ \\
LDEP & -0.385353 & $-4.587426 *$ \\
LDF & -1.198550 & $-3.113928 *$ \\
LFBC & $-3.432071 *$ & $-5.069029 *$ \\
CHL & $-2.645543 *$ & $-7.557805 *$ \\
LCER & -1.872987 & $-5.336367 *$ \\
LCBEC & -1.432657 & $-5.150880 *$ \\
\hline
\end{tabular}

Note: In this test, the p-value is compared to $10 \%$. If the probabilities $<10 \%$ therefore we reject the null hypothesis and the probabilities $>10 \%$ then we accept the null hypothesis. With the null hypothesis all series are non-stationary. $(*),(* *)$ and $(* * *)$ are significant values for the $1 \%$ and $5 \%$ respectively.

\subsection{The Cointegration Test}

We will present in this part of the test results of cointegration. The test of Engle-Granger cointegration is applied to ensure the long-term relationship between the variables used in this paper to examine the impact of FDI on poverty and sustainable development in Tunisia.

- The method used by Engle and Granger (1987) is based on two steps: 
- The first step is to estimate equation or cointégrations regression by ordinary least squares (OLS) knowing that $\mathrm{Xt}$ and $\mathrm{Yt}$ are integrated of order 1. This operation will extract the estimated residuals;

The second step will be to test the stationarity of residuals generated from the first stage. If these are stationary, the variables listed in the above regression are cointegrated. Engle and Granger advocate for this, the use of increased Dickey-Fuller test (ADF).

According to the results of both Tables; 4, 5, 6 and 7, we confirmed the existence of a cointegration relationship between the different series studied in this paper. Indeed, the results of the null hypothesis test of no cointegration were rejected at the $5 \%$ threshold, which explains the presence of a cointegration relationship.

The results of these tests can determine the use of an error correction model. Also, to test the effect of FDI on poverty and sustainable development in Tunisia, we will perform a FMOLS estimate.

Table 4. The test cointegration the impact of FDI on poverty (GINI) for the case of the countries of North Africa

\begin{tabular}{lllll}
\hline dependent & tau-statistic & Prob. ${ }^{*}$ & z-statistic & Prob. ${ }^{*}$ \\
\hline FDI & -4.357993 & 0.0085 & -24.15673 & 0.0046 \\
GINI & -15.54587 & 0.0000 & -136.7007 & 0.0000 \\
\hline
\end{tabular}

* MacKinnon (1996) p-values.

Table 5. The test cointegration the impact of FDI on poverty (\$ POV1_91) for the case of the countries of North Africa

\begin{tabular}{lllll}
\hline dependent & tau-statistic & Prob. ${ }^{*}$ & z-statistic & Prob. ${ }^{*}$ \\
\hline FDI & -4.369969 & 0.0082 & -24.21766 & 0.0045 \\
\$ POV1_91 & -13.80144 & 0.0000 & -44.85211 & 0.0000 \\
\hline
\end{tabular}

* MacKinnon (1996) p-values.

Table 6. The test cointegration the impact of FDI on poverty (\$POV3_1) for the case of the countries of North Africa

\begin{tabular}{lllll}
\hline dependent & tau-statistic & Prob. ${ }^{*}$ & z-statistic & Prob. ${ }^{*}$ \\
\hline FDI & -4.308539 & 0.0095 & -23.80511 & 0.0052 \\
\$ POV3_1 & -13.49753 & 0.0000 & -17.89483 & 0.0000 \\
\hline
\end{tabular}

* MacKinnon (1996) p-values.

Table 7. The Impact cointegration test of FDI on $\mathrm{CO} 2$ emissions for those countries of North Africa

\begin{tabular}{lllll}
\hline dependent & tau-statistic & Prob. ${ }^{*}$ & z-statistic & Prob. ${ }^{*}$ \\
\hline FDI & -4.690013 & 0.0039 & -26.25178 & 0.0020 \\
CO2 & -1.137931 & 0.8744 & -2.813612 & 0.8872 \\
\hline
\end{tabular}

* MacKinnon (1996) p-values.

\subsection{The Error Correction Model}

After testing the cointegration between FDI on sustainable development and poverty in our paper, we'll estimate the model for correction of errors.

The MCE allows modeled together for short-term dynamics (represented by the variables in first differences) and long term (represented by the variables in level).

Table 8,9,10 and 11 summarize the estimated error correction model for the three poverty indicators and emissions of CO2 in the case of Tunisia during the study period of 1985 to 2015.

Table 8 summarizes the estimated error correction model for poverty measured by the GINI index for the case of Tunisia during the study period of 1985 to 2015 . 
For LIDE variable and studying the short-term dynamics, we notice that only the unemployment rate measured by $\mathrm{LCH}$ has a negative and significant impact on foreign direct investment with a threshold of $1 \%$. That is to say, if the level of the unemployment rate increased by one, then, foreign direct investment fell by 14.42371 units.

For the first measurement of poverty LGINI, we notice that the LCBEC variable that measures the market capitalization of listed companies is statistically significant and negative on poverty at a $10 \%$ threshold. So if the market capitalization of listed companies increased by ten units then, poverty decreases by 0.073111 units.

So, we notice that the LDF variable that measures the financial development has a positive and significant impact on poverty at a $10 \%$ threshold. That is to say, if the level of financial development increases by ten units, then, poverty increases 0.422133 units.

We notice that the LTAJ variable that measures the youth literacy rate has a negative impact on poverty measured by poverty measured by the Gini index LGINI a $10 \%$ threshold. That is to say, if the youth literacy rate increases of 10 units, then poverty, as measured by the GINI index, decreases by 0.350728 units.

Table 8 . The MCE for variable LGINI

\begin{tabular}{|c|c|c|}
\hline Cointegrating Eq: & CointEq1 & \\
\hline LIDE (-1) & 1.000000 & \\
\hline \multirow[t]{3}{*}{ LGINI (-1) } & 10.04968 & \\
\hline & $(21.2011)$ & \\
\hline & {$[0.47402]$} & \\
\hline $\mathrm{C}$ & -39.55332 & \\
\hline Error correction: & $\mathrm{D}$ (IDE) & D (Gini) \\
\hline \multirow[t]{3}{*}{ CointEq1 } & -1.556260 & 0.014560 \\
\hline & $(0.54388)$ & $(0.00919)$ \\
\hline & {$[-2.86138] *$} & [1.58520] \\
\hline \multirow[t]{3}{*}{$\mathrm{D}(\operatorname{LIDE}(-1))$} & 0.160921 & -0.009938 \\
\hline & $(0.44711)$ & $(0.00755)$ \\
\hline & [0.35991] & {$[-1.31618]$} \\
\hline \multirow[t]{3}{*}{ D (LIDE (-2)) } & 0.252904 & -0.003708 \\
\hline & $(0.27497)$ & $(0.00464)$ \\
\hline & [0.91974] & {$[-0.79839]$} \\
\hline \multirow[t]{3}{*}{ D (LGINI (-1)) } & -31.61112 & -0.557835 \\
\hline & $(23.4729)$ & $(0.39641)$ \\
\hline & {$[-1.34671]$} & {$[-1.40721]$} \\
\hline \multirow[t]{3}{*}{ D (LGINI (-2)) } & -10.95665 & -0.185064 \\
\hline & $(14.4646)$ & $(0.24428)$ \\
\hline & {$[-0.75748]$} & {$[-0.75759]$} \\
\hline \multirow[t]{3}{*}{$\mathrm{C}$} & 105.4834 & 6.709207 \\
\hline & $(269,563)$ & $(4.55240)$ \\
\hline & [0.39131] & [1.47377] \\
\hline \multirow[t]{3}{*}{ LCBEC } & -2.618935 & -0.073111 \\
\hline & $(2.34464)$ & $(0.03960)$ \\
\hline & [-1.11699] & {$[-1.84640] * * *$} \\
\hline \multirow[t]{3}{*}{ LCER } & 10.01507 & -0.250160 \\
\hline & (18.1426) & $(0.30639)$ \\
\hline & {$[0.55202]$} & {$[-0.81646]$} \\
\hline \multirow[t]{3}{*}{ CHL } & -14.42371 & -0.019639 \\
\hline & $(5.32843)$ & $(0.08999)$ \\
\hline & {$[-2.70693] *$} & {$[-0.21824]$} \\
\hline \multirow[t]{3}{*}{ LDEP } & -0.835140 & -0.136710 \\
\hline & $(9.77780)$ & $(0.16513)$ \\
\hline & {$[-0.08541]$} & {$[-0.82790]$} \\
\hline \multirow[t]{3}{*}{ LDF } & 6.803675 & 0.422133 \\
\hline & $(12.8831)$ & $(0.21757)$ \\
\hline & {$[0.52811]$} & {$[1.94021] * * *$} \\
\hline
\end{tabular}




\begin{tabular}{lll}
\hline LFBC & 0.136146 & -0.007306 \\
& $(0.34872)$ & $(0.00589)$ \\
& {$[0.39042]$} & {$[-1.24059]$} \\
LINF & -0.559164 & 0.012804 \\
& $(0.54024)$ & $(0.00912)$ \\
& {$[-1.03504]$} & {$[1.40343]$} \\
LPIB & -0.093453 & 0.003212 \\
& $(0.33541)$ & $(0.00566)$ \\
& {$[-0.27863]$} & {$[0.56709]$} \\
LPU & -17.64447 & -0.950062 \\
& $(74.9448)$ & $(1.26568)$ \\
& {$[-0.23543]$} & {$[-0.75064]$} \\
LTAJ & 7.861463 & -0.350728 \\
& $(12.4220)$ & $(0.20978)$ \\
& {$[0.63287]$} & {$[-1.67186] * * *$} \\
LUE & -3.061452 & -0.382057 \\
& $(19.2856)$ & $(0.32570)$ \\
& {$[-0.15874]$} & {$[-1.17305]$} \\
LCO2 & -6.106769 & 0.027711 \\
& $(11.2525)$ & $(0.19003)$ \\
R-squared & {$[-0.54270]$} & {$[0.14582]$} \\
Adj. R-squared & 0.866956 & 0.678132 \\
a & 0.640782 & 0.130957 \\
\hline
\end{tabular}

Note: $(*)(* *)$ and $(* * *)$ are significant values for the $1 \%, 5 \%$ and $10 \%$ respectively

Table 9 summarizes the estimated error correction model for poverty measured by the poverty gap of $\$ 1.91$ for the case of Tunisia during the study period of 1985 to 2015.

For LIDE variable, and studying the short-term dynamics, we notice that there are no significant variables.

For the second measure of poverty \$ LPOV1_91, we also notice that there are no significant variable.

Table 9. The MCE for the variable \$ LPOV1_91

\begin{tabular}{lll}
\hline Cointegrating Eq: & CointEq1 & \\
\hline LIDE (-1) & 1.000000 & \\
\hline LPOV1_91 \$ (- 1) & 1.428765 & \\
& $(1.61001)$ & \\
& {$[0.88743]$} & \\
C & -2.893630 & \\
Error correction: & D (IDE) & D (POV1_91 \$) \\
CointEq1 & -1.883606 & -0.001519 \\
& $(0.58543)$ & $(0.10006)$ \\
& {$[-3.21745] *$} & {$[-0.01518]$} \\
D (LIDE (-1)) & 0.541594 & 0.024419 \\
& $(0.48821)$ & $(0.08344)$ \\
& {$[1.10935]$} & {$[0.29264]$} \\
D (LIDE (-2)) & 0.433097 & 0.023821 \\
& $(0.37255)$ & $(0.06368)$ \\
& {$[1.16253]$} & {$[0.37410]$} \\
D (LPOV1_91 \$ (- 1)) & -0.141350 & -0.463092 \\
& $(2.09302)$ & $(0.35774)$ \\
& {$[-0.06753]$} & {$[-1.29451]$} \\
D (LPOV1_91 \$ (- 2)) & -0.276010 & -0.202540 \\
& $(1.81664)$ & $(0.31050)$ \\
& {$[-0.15193]$} & {$[-0.65231]$} \\
C & 77.07930 & -0.021304 \\
\hline
\end{tabular}




\begin{tabular}{|c|c|c|}
\hline & $(297,878)$ & $(50.9128)$ \\
\hline & {$[0.25876]$} & {$[-0.00042]$} \\
\hline \multirow[t]{3}{*}{ LCBEC } & -0.606293 & -0.332250 \\
\hline & (2.78879) & $(0.47666)$ \\
\hline & {$[-0.21740]$} & {$[-0.69705]$} \\
\hline \multirow{3}{*}{ LCER } & 4.614981 & 1.938490 \\
\hline & (23.1190) & (3.95145) \\
\hline & [0.19962] & {$[0.49058]$} \\
\hline \multirow[t]{3}{*}{ CHL } & -7.332022 & -0.180508 \\
\hline & (6.05308) & $(1.03458)$ \\
\hline & [-1.21129] & {$[-0.17447]$} \\
\hline \multirow[t]{3}{*}{ LDEP } & -12.36037 & 0.098890 \\
\hline & (12.1150) & (2.07068) \\
\hline & [-1.02025] & [0.04776] \\
\hline \multirow[t]{3}{*}{ LDF } & 0.148350 & 2.180808 \\
\hline & (12.4315) & $(2.12477)$ \\
\hline & [0.01193] & [1.02637] \\
\hline \multirow[t]{3}{*}{ LFBC } & 0.474089 & -0.045290 \\
\hline & $(0.36872)$ & $(0.06302)$ \\
\hline & [1.28577] & {$[-0.71865]$} \\
\hline \multirow{3}{*}{ LINF } & 0.135654 & 0.044310 \\
\hline & $(0.52142)$ & $(0.08912)$ \\
\hline & [0.26016] & [0.49719] \\
\hline \multirow[t]{3}{*}{ LPIB } & -0.302292 & 0.016810 \\
\hline & (0.30619) & $(0.05233)$ \\
\hline & [-0.98728] & {$[0.32121]$} \\
\hline \multirow[t]{3}{*}{ LPU } & 52.40587 & 0.790337 \\
\hline & (72.0941) & (12.3222) \\
\hline & {$[0.72691]$} & {$[0.06414]$} \\
\hline \multirow[t]{3}{*}{ LTAJ } & 8.944404 & 0.670726 \\
\hline & $(14.1661)$ & $(2.42124)$ \\
\hline & {$[0.63140]$} & {$[0.27702]$} \\
\hline \multirow[t]{3}{*}{ LUE } & -21.81508 & -1.112633 \\
\hline & (25.3042) & (4.32496) \\
\hline & {$[-0.86211]$} & {$[-0.25726]$} \\
\hline \multirow[t]{3}{*}{$\mathrm{LCO} 2$} & -19.82642 & -1.369676 \\
\hline & (12.9262) & $(2.20931)$ \\
\hline & [-1.53382] & {$[-0.61996]$} \\
\hline R-squared & 0.805886 & 0.413283 \\
\hline Adj. R-squared & 0.475893 & -0.584135 \\
\hline
\end{tabular}

Note: $(*)(* *)$ and $(* * *)$ are significant values for the $1 \%, 5 \%$ and $10 \%$ respectively

Table 10 summarizes the estimated error correction model for poverty measured by poverty gap of $\$ 3.1$ for the case of Tunisia during the study period of 1985 to 2015.

For LIDE variable, and studying the short-term dynamics, we notice that only the unemployment rate measured by LCH has a negative and significant impact on foreign direct investment at a $10 \%$ threshold. That is to say, if the level of unemployment rises to ten units, then, foreign direct investment fell by 9.486470 units.

For the second measure of poverty \$ LPOV3_1, we also find that there are no significant variable. 
Table 10. The MCE for the variable \$ LPOV3_1

\begin{tabular}{|c|c|c|}
\hline Cointegrating Eq: & CointEq1 & \\
\hline LIDE (-1) & 1.000000 & \\
\hline \multirow[t]{3}{*}{ LPOV3_1 \$ (-1) } & 1.870956 & \\
\hline & $(2.29017)$ & \\
\hline & [0.81695] & \\
\hline $\mathrm{C}$ & -5.751663 & \\
\hline Error correction: & $\mathrm{D}$ (LIDE) & D (LPOV3_1\$) \\
\hline \multirow[t]{3}{*}{ CointEq1 } & -1.869509 & 0.036181 \\
\hline & $(0.51547)$ & $(0.06670)$ \\
\hline & {$[-3.62678] *$} & [0.54243] \\
\hline \multirow[t]{3}{*}{$\mathrm{D}(\operatorname{LIDE}(-1))$} & 0.469604 & -0.008236 \\
\hline & $(0.42716)$ & $(0.05527)$ \\
\hline & [1.09936] & {$[-0.14900]$} \\
\hline \multirow[t]{3}{*}{$\mathrm{D}(\operatorname{LIDE}(-2))$} & 0.423835 & 0.006181 \\
\hline & $(0.31386)$ & $(0.04061)$ \\
\hline & [1.35038] & {$[0.15218]$} \\
\hline \multirow[t]{3}{*}{ D (LPOV3_1 \$ (- 1)) } & -1.851312 & -0.529460 \\
\hline & $(2.60155)$ & $(0.33664)$ \\
\hline & {$[-0.71162]$} & {$[-1.57277]$} \\
\hline \multirow[t]{3}{*}{ D (LPOV3_1 \$ (-2)) } & -0.993832 & -0.187088 \\
\hline & $(2.03015)$ & $(0.26270)$ \\
\hline & {$[-0.48954]$} & {$[-0.71217]$} \\
\hline \multirow[t]{3}{*}{$\mathrm{C}$} & 106.6418 & 11.33600 \\
\hline & $(270,598)$ & $(35.0153)$ \\
\hline & {$[0.39410]$} & {$[0.32374]$} \\
\hline \multirow[t]{3}{*}{ LCBEC } & -0.768479 & -0.474253 \\
\hline & $(2.48714)$ & $(0.32184)$ \\
\hline & {$[-0.30898]$} & {$[-1.47359]$} \\
\hline \multirow[t]{3}{*}{ LCER } & 8.748846 & 0.707479 \\
\hline & $(20.0414)$ & $(2.59335)$ \\
\hline & {$[0.43654]$} & {$[0.27281]$} \\
\hline \multirow[t]{3}{*}{$\mathrm{CHL}$} & -9.486470 & -0.202099 \\
\hline & $(5.44207)$ & $(0.70420)$ \\
\hline & {$[-1.74317] * * *$} & {$[-0.28699]$} \\
\hline \multirow[t]{3}{*}{ LDEP } & -11.88459 & 0.447405 \\
\hline & $(10.6081)$ & (1.37269) \\
\hline & {$[-1.12033]$} & [0.32593] \\
\hline \multirow[t]{3}{*}{ LDF } & 2.414160 & 2.070995 \\
\hline & (11.6091) & $(1.50222)$ \\
\hline & {$[0.20795]$} & {$[1.37862]$} \\
\hline \multirow[t]{3}{*}{ LFBC } & 0.339044 & -0.037307 \\
\hline & $(0.34480)$ & $(0.04462)$ \\
\hline & [0.98330] & {$[-0.83616]$} \\
\hline \multirow[t]{3}{*}{ LINF } & -0.069379 & 0.053580 \\
\hline & $(0.48110)$ & $(0.06225)$ \\
\hline & {$[-0.14421]$} & {$[0.86066]$} \\
\hline \multirow[t]{3}{*}{ LPIB } & -0.224194 & 0.021662 \\
\hline & $(0.29456)$ & $(0.03812)$ \\
\hline & {$[-0.76113]$} & {$[0.56832]$} \\
\hline \multirow[t]{3}{*}{ LPU } & 31.39818 & -2.046920 \\
\hline & $(67.7016)$ & $(8.76057)$ \\
\hline & {$[0.46377]$} & {$[-0.23365]$} \\
\hline \multirow{3}{*}{ LTAJ } & 8.420514 & -0.679437 \\
\hline & (12.9511) & (1.67587) \\
\hline & {$[0.65018]$} & {$[-0.40542]$} \\
\hline
\end{tabular}




\begin{tabular}{lll}
\hline LUE & -18.10771 & -0.947334 \\
& $(21.7788)$ & $(2.81818)$ \\
LCO2 & {$[-0.83144]$} & {$[-0.33615]$} \\
& -16.68377 & -0.513325 \\
& $(11.5880)$ & $(1.49948)$ \\
R-squared & {$[-1.43975]$} & {$[-0.34233]$} \\
Adj. R-squared & 0.843418 & 0.533498 \\
\hline
\end{tabular}

Note: $(*)(* *)$ and $(* * *)$ are significant values for the $1 \%, 5 \%$ and $10 \%$ respectively

Table 11 summarizes the estimated error correction model for sustainable development and for the countries of North Africa during the study period of 1985 to 2015. For LIDE variable, and studying the short-term dynamics, we remark that there are no significant variables.

For $\mathrm{CO} 2$ emissions (LCO2), we notice that the IDE (t-1) have a positive and significant impact on a threshold of $1 \%$ on Sustainable Development at time $t$ in the case of Tunisia. That is to say, if the IDE at the time (t-1) increased by one unit then the $\mathrm{CO} 2$ emissions increase of 0.027008 units.

Moreover, foreign direct investment ( $\mathrm{t}-2)$ have a positive and significant impact on a threshold of $1 \%$ on sustainable development measured by $\mathrm{CO} 2$ emissions at time $\mathrm{t}$ in the case of Tunisia. That is to say, if foreign direct investment at the time (t-2) increased by one unit then the $\mathrm{CO} 2$ emissions increase of 0.018978 units.

We noticed that emissions of $\mathrm{CO} 2$ at the time (t-1) has a negative and significant effect on $\mathrm{CO} 2$ emissions at time $\mathrm{t}$ with a threshold of 5\%. This means that if the $\mathrm{CO} 2$ emissions at the time $(\mathrm{t}-1)$ increased by five units then they decrease of 1.004283 units at time $t$.

Also, emissions of $\mathrm{CO} 2$ at the time (t-2) has a negative and significant effect on $\mathrm{CO} 2$ emissions at time $\mathrm{t}$ with a threshold of 5\%. This means that if emissions of $\mathrm{CO} 2$ at the time (t-2) increase of five units then they decrease of 0.647582 units at time $\mathrm{t}$.

We noted that the unemployment rate measured by LCH has a positive and significant impact on emissions of $\mathrm{CO} 2$ at a $10 \%$ threshold. That is to say, if the level of unemployment rises to ten units, then the $\mathrm{CO} 2$ emissions increase of 0.223942 units.

Finally, is statistically significant and positive at a $1 \%$ level. LFBC tied variable which measures the gross formation of capital stock also has a positive and significant impact on foreign direct investment with a threshold of $1 \%$. That is to say, if the level of gross fixed capital stock increases by one, while foreign direct investment increased by 0.019047 unités.

Table 11. The MCE for variable $\mathrm{LCO} 2$

\begin{tabular}{lll}
\hline Cointegrating Eq: & CointEq1 & \\
\hline LIDE (-1) & 1.000000 & \\
\hline LCO2 (-1) & 3.069396 & \\
& $(6.59386)$ & \\
& {$[0.46549]$} & \\
C & -32.84811 & \\
Error correction: & D (LIDE) & D (LCO2) \\
CointEq1 & -1.222783 & -0.030979 \\
& $(0.70270)$ & $(0.00894)$ \\
& {$[-1.74012] * * *$} & {$[-3.46475] *$} \\
D (LIDE (-1)) & 0.010637 & 0.027008 \\
& $(0.59820)$ & $(0.00761)$ \\
& {$[0.01778]$} & {$[3.54832]$} \\
D (LIDE (-2)) & -0.005564 & 0.018978 \\
& $(0.42560)$ & $(0.00542)$ \\
& {$[-0.01307]$} & {$[3.50450]$} \\
D (LCO2 (-1)) & -14.62163 & -1.004283 \\
& $(27.1953)$ & $(0.34603)$ \\
\hline
\end{tabular}




\begin{tabular}{|c|c|c|}
\hline & {$[-0.53765]$} & {$[-2.90226] * *$} \\
\hline \multirow[t]{3}{*}{$\mathrm{D}(\mathrm{LCO} 2(-2))$} & -7.845530 & -0.647582 \\
\hline & (21.8646) & $(0.27821)$ \\
\hline & {$[-0.35882]$} & {$[-2.32770] * *$} \\
\hline \multirow[t]{3}{*}{$\mathrm{C}$} & 323.2986 & -2.733106 \\
\hline & $(538,346)$ & $(6.84995)$ \\
\hline & {$[0.60054]$} & {$[-0.39900]$} \\
\hline \multirow[t]{3}{*}{ LGINI } & -53.16490 & 0.116662 \\
\hline & $(66.4531)$ & $(0.84555)$ \\
\hline & {$[-0.80004]$} & [0.13797] \\
\hline \multirow[t]{3}{*}{ \$ LPOV1_91 } & 1.967789 & -0.206890 \\
\hline & (11.4486) & $(0.14567)$ \\
\hline & [0.17188] & {$[-1.42024]$} \\
\hline \multirow[t]{3}{*}{ \$ LPOV3_1 } & -2.556396 & 0.250888 \\
\hline & (18.6107) & $(0.23680)$ \\
\hline & {$[-0.13736]$} & [1.05948] \\
\hline \multirow[t]{3}{*}{ LCBEC } & -9.192779 & 0.070591 \\
\hline & (6.41957) & $(0.08168)$ \\
\hline & [-1.43199] & {$[0.86420]$} \\
\hline \multirow[t]{3}{*}{ LCER } & -0.988499 & 0.515490 \\
\hline & (26.8308) & $(0.34140)$ \\
\hline & {$[-0.03684]$} & [1.50994] \\
\hline \multirow{3}{*}{ CHL } & -11.29424 & 0.223942 \\
\hline & $(9.43296)$ & $(0.12003)$ \\
\hline & {$[-1.19732]$} & {$[1.86578] * * *$} \\
\hline \multirow[t]{3}{*}{ LDEP } & -9.598825 & -0.181244 \\
\hline & (16.7448) & $(0.21306)$ \\
\hline & {$[-0.57324]$} & {$[-0.85066]$} \\
\hline \multirow[t]{3}{*}{ LDF } & 17.72742 & -0.156138 \\
\hline & (22.1032) & $(0.28124)$ \\
\hline & [0.80203] & {$[-0.55517]$} \\
\hline \multirow[t]{3}{*}{ LFBC } & 0.241827 & 0.019047 \\
\hline & $(0.51355)$ & $(0.00653)$ \\
\hline & [0.47089] & {$[2.91490] *$} \\
\hline \multirow[t]{3}{*}{ LINF } & 0.379195 & -0.001407 \\
\hline & $(0.57684)$ & $(0.00734)$ \\
\hline & {$[0.65736]$} & [-0.19163] \\
\hline \multirow[t]{3}{*}{ LPIB } & -0.290467 & -0.006056 \\
\hline & $(0.37794)$ & $(0.00481)$ \\
\hline & {$[-0.76854]$} & [-1.25926] \\
\hline \multirow[t]{3}{*}{ LPU } & -54.25991 & 0.648871 \\
\hline & (87.5338) & (1.11379) \\
\hline & {$[-0.61987]$} & {$[0.58258]$} \\
\hline \multirow[t]{3}{*}{ LTAJ } & 5.662758 & 0.203961 \\
\hline & (18.6942) & $(0.23787)$ \\
\hline & [0.30291] & {$[0.85746]$} \\
\hline \multirow[t]{3}{*}{ LUE } & 18.75458 & -0.647410 \\
\hline & (33.8638) & $(0.43089)$ \\
\hline & {$[0.55382]$} & {$[-1.50251]$} \\
\hline R-squared & 0.812323 & 0.924408 \\
\hline Adj. R-squared & 0.366590 & 0.744878 \\
\hline
\end{tabular}

Note: $(*)(* *)$ and $(* * *)$ are significant values for the $1 \%, 5 \%$ and $10 \%$ respectively 


\subsection{The Estimation Results FMOLS}

The panel FMOLS method proposed by Pedroni $(1996,2000)$ solves problems of heterogeneity in the sense that it allows the use of heterogeneous cointegrating vectors. For Maeso-Fernandez et al. (2004), FMOLS estimator takes into account the presence of the constant term and the possible existence of correlation between the error term and differences estimators.

Adjustments are made to this effect on the dependent variable and long-term parameters obtained by estimating the fitted equation. In the case of panel data, the long-term coefficients from the FMOLS art are obtained by the average group of estimators with respect to the sample size $(\mathrm{N})$.

The estimate of the four models is summarized in Tables 12, 13, 14 and 15.

In addition, the determination of coefficients for the four estimated models are higher than 0.7 , therefore, the four estimated models are characterized by a good linear fit.

The first is the variable For FMOLS estimate of the first indicator of poverty, we noticed that there are ten significant variables, but with different signs (Table 12).

We find that the LIDE variable measuring foreign direct investment has a significant negative impact on the Gini index to a threshold of $1 \%$. That is to say, if the level of FDI increases by one, then poverty as measured by the GINI index decreases by 0.004479 units.

The LCBEC variable that measures the market capitalization of listed companies is negative and statistically significant at a threshold of $1 \%$. So if the market capitalization of listed companies increased by one then, poverty measured by the GINI index decreases by 0.066272 units.

We notice that the LDEP variable measuring government spending has a negative impact on poverty as measured by the GINI index to a threshold of 5\%. That is to say, if the level of public spending increases of five units, then poverty as measured by the GINI index decreases by 0.123287 units.

So we notice that the LDF variable that measures the financial development has a positive and significant impact on poverty at a threshold of $1 \%$. That is to say, if the level of financial development increases by one, then poverty as measured by the GINI index increases by 0.135372 units.

Is statistically significant and positive at a $1 \%$ level. nouThe LFBC variable that measures the gross formation of capital stock also has a negative and significant impact on the Gini index to a threshold of $1 \%$. That is to say, if the level of gross fixed capital stock increases by one, then, poverty decreases by 0.004864 units.

We notice that the LINF variable that measures the rate of inflation has a positive impact on poverty as measured by the GINI index to a threshold of 5\%. That is to say, if the inflation rate increases by five units, then poverty as measured by the GINI index increases by 0.004743 units.

Is statistically significant and positive at a $1 \%$ level. nouThe LPU variable that measures the urban population also has a significant negative impact on the Gini index to a threshold of 5\%. That is to say, if the level of the urban population increases by five units, then, poverty decreases by 0.453455 units.

We find that the LTAJ variable which measures the youth literacy rate has a negative impact on poverty measured by the Gini index to a threshold of $1 \%$. That is to say, if the youth literacy rate increments, then, poverty measured by the Gini index decreases 0.215407 units.

Finally, the LUE variable which measures the level of energy consumption is statistically significant and positive for a threshold of $5 \%$. So if the power consumption increases five units then, poverty measured by the GINI index increases by 0.206150 units.

Table 12. Estimated FMOLS for variable LGINI

\begin{tabular}{lllll}
\hline Variable & Coefficient & Std. error & Does Statistic & Prob. \\
\hline LIDE & -0.004479 & 0.001268 & $-3.530955^{*}$ & 0.0028 \\
LCO2 & -0.066454 & 0.050518 & -1.315444 & 0.2069 \\
LCBEC & -0.066272 & 0.010567 & $-6.271808 *$ & 0.0000 \\
LCER & 0.101503 & 0.073312 & 1.384536 & 0.1852 \\
CHL & -0.045017 & 0.027370 & -1.644752 & 0.1195 \\
LDEP & -0.123287 & 0.051857 & $-2.377439 * *$ & 0.0302 \\
LDF & 0.135372 & 0.034470 & $3.927273 *$ & 0.0012 \\
\hline
\end{tabular}




\begin{tabular}{lllll}
\hline LFBC & -0.004864 & 0.001428 & $-3.407524 *$ & 0.0036 \\
LINF & 0.004743 & 0.002269 & $2.090857 * *$ & 0.0529 \\
LPIB & 0.000173 & 0.001101 & 0.157209 & 0.8770 \\
LPU & -0.453455 & 0.201575 & $-2.249557^{* *}$ & 0.0389 \\
LTAJ & -0.215407 & 0.064348 & $-3.347532 *$ & 0.0041 \\
LUE & 0.206150 & 0.095001 & $2.169966 * *$ & 0.0454 \\
C & 6.224334 & 0.907060 & $6.862101 *$ & 0.0000 \\
R-squared & 0.954584 & Mean dependent var & 3.679096 \\
Adjusted R-squared & 0.917683 & \multicolumn{2}{c}{ SD dependent var } & 0.065703 \\
\hline
\end{tabular}

Note: $(*)(* *)$ and $(* * *)$ are significant values for the $1 \%, 5 \%$ and $10 \%$ respectively

The first is the variable For FMOLS estimate of second indicator of poverty, we notice that there are four significant variables, but with different signs (Table 13).

We find that the $\mathrm{LCO} 2$ variable that measures the $\mathrm{CO} 2$ emissions has a negative and significant impact on poverty as measured by the poverty gap at $\$ 1.91$ a threshold of $1 \%$. That is to say, if the level of $\mathrm{CO} 2$ emissions will increase by one, then poverty as measured by the poverty gap at $\$ 1.91$ reduced by 5.277719 units.

We notice that the LDEP variable measuring government spending has a negative impact on poverty as measured by the poverty gap at $\$ 1.91$ a threshold of $1 \%$. That is to say, if the level of public spending increases by one, then poverty as measured by the poverty gap at $\$ 1.91$ reduced by 2.138600 units.

We notice that the LINF variable that measures the rate of inflation has a positive impact on poverty as measured by the poverty gap at $\$ 1.91$ for a $10 \%$ threshold. That's to say, if inflation increases by ten units, then poverty as measured by the poverty gap at $\$ 1.91$ increases 0.059823 units.

Is statistically significant and positive at a $1 \%$ level. nouThe LPU variable that measures the urban population also has a negative and significant impact on poverty as measured by the poverty gap at $\$ 1.91$ a threshold of $1 \%$. That is to say, if the level of the urban population increases by one, then poverty as measured by the poverty gap at \$1.91 increases 11.00534 units.

Table 13. Estimated FMOLS for the variable \$ LPOV1_91

\begin{tabular}{crrrr}
\hline Variable & Coefficient & Std. error & Does Statistic & Prob. \\
\hline LIDE & -0.027674 & 0.017861 & -1.549436 & 0.1408 \\
LCO2 & -5.277719 & 0.711387 & $-7.418919 *$ & 0.0000 \\
LCBEC & 0.011670 & 0.148798 & 0.078427 & 0.9385 \\
LCER & 0.385408 & 1.032363 & 0.373326 & 0.7138 \\
CHL & 0.374543 & 0.385425 & 0.971767 & 0.3456 \\
LDEP & -2.138600 & 0.730244 & $-2.928610 *$ & 0.0098 \\
LDF & 0.491911 & 0.485397 & 1.013419 & 0.3259 \\
LFBC & 0.020985 & 0.020102 & 1.043911 & 0.3120 \\
LINF & 0.059823 & 0.031946 & $1.872598 * * *$ & 0.0795 \\
LPIB & -0.007276 & 0.015501 & -0.469407 & 0.6451 \\
LPU & 11.00534 & 2.838548 & $3.877101 *$ & 0.0013 \\
LTAJ & -0.150441 & 0.906140 & -0.166024 & 0.8702 \\
LUE & -2.043905 & 1.337793 & -1.527818 & 0.1461 \\
C & 19.11309 & 12.77307 & 1.496358 & 0.1540 \\
R-squared & 0.965715 Mean dependent var & 0.218159 \\
Adjusted R-squared & 0.937859 & SD dependent var & 0.810581 \\
\hline
\end{tabular}

Note: $(*)(* *)$ and $(* * *)$ are significant values for the $1 \%, 5 \%$ and $10 \%$ respectively 
The first is the variable For FMOLS estimate of third indicator of poverty, we noticed that there are six significant variables, but with different signs (Table 14).

We find that the LIDE variable measuring foreign direct investment has a negative and significant impact on poverty as measured by the poverty gap at $\$ 3.1$ with a 5\% threshold. That is to say, if the level of FDI increases five units, then poverty as measured by the poverty gap at $\$ 3.1$ decreases 0.028766 units.

We find that the $\mathrm{LCO} 2$ variable that measures the $\mathrm{CO} 2$ emissions has a negative and significant impact on poverty as measured by the poverty gap at $\$ 3.1$ with a threshold of $1 \%$. That is to say, if the level of $\mathrm{CO} 2$ emissions will increase by one, then poverty as measured by the poverty gap at $\$ 3.1$ decreases 3.343223 units.

The LCBEC variable that measures the market capitalization of listed companies is negative and statistically significant at a threshold of 5\%. So if the market capitalization of listed companies increased by five units then measured by the poverty gap of $\$ 3.1$ poverty decreases by 0.196622 units.

We notice that the LDEP variable measuring government spending has a negative impact on poverty measured by the poverty gap at $\$ 3.1$ with a 5\% threshold. That is to say, if the level of public spending increases of five units, then poverty as measured by the poverty gap at $\$ 3.1$ decreases 1.246966 units.

We notice that the LINF variable that measures the rate of inflation has a positive impact on poverty as measured by the poverty gap at $\$ 3.1$ with a $10 \%$ threshold. That is to say, if the inflation rate increases by ten units, then poverty as measured by the poverty gap at $\$ 3.1$ increases 0.038112 units.

, Is statistically significant and positive at a $1 \%$ level. nouThe LPU variable that measures the urban population also has a positive and significant impact on poverty as measured by the poverty gap at $\$ 3.1$ with a threshold of $1 \%$. That is to say, if the level of the urban population increases by one, then poverty as measured by the poverty gap at $\$ 3.1$ increases 6.452835 units.

Table 14. Estimated FMOLS for the variable \$ LPOV3_1

\begin{tabular}{lllll}
\hline Variable & Coefficient & Std. error & Does Statistic & Prob. \\
\hline LIDE & -0.028766 & 0.010978 & $-2.620453 * *$ & 0.0186 \\
LCO2 & -3.343223 & 0.437231 & $-7.646347 *$ & 0.0000 \\
LCBEC & -0.196622 & 0.091454 & $-2.149945 * *$ & 0.0472 \\
LCER & 0.455948 & 0.634510 & 0.718583 & 0.4828 \\
CHL & -0.076941 & 0.236889 & -0.324798 & 0.7495 \\
LDEP & -1.246966 & 0.448822 & $-2.778310 * *$ & 0.0134 \\
LDF & 0.308771 & 0.298334 & 1.034985 & 0.3161 \\
LFBC & 0.015322 & 0.012355 & 1.240113 & 0.2328 \\
LINF & 0.038112 & 0.019635 & $1.941059 * * *$ & 0.0701 \\
LPIB & -0.008345 & 0.009527 & -0.875918 & 0.3940 \\
LPU & 6.452835 & 1.744625 & $3.698696 *$ & 0.0019 \\
LTAJ & -0.691848 & 0.556930 & -1.242251 & 0.2320 \\
LUE & -0.147313 & 0.822233 & -0.179162 & 0.8601 \\
C & 13.70280 & 7.850566 & 1.745454 & 0.1001 \\
R-squared & 0.972428 & Mean dependent var & 1.690367 \\
Adjusted R-squared & 0.950026 & \multicolumn{2}{c}{ SD dependent var } & 0.625273 \\
\hline
\end{tabular}

Note: $(*)(* *)$ and $(* * *)$ are significant values for the $1 \%, 5 \%$ and $10 \%$ respectively

The first is the variable For FMOLS estimate of sustainable development, we notice that there are 11 significant variables, but with different signs (Table 15).

We find that the LGINI variable measuring poverty has a positive impact on emissions of $\mathrm{CO} 2$ at a threshold of $1 \%$. That is to say, if poverty increases by one, then the $\mathrm{CO} 2$ emissions increase of 0.858714 units.

We notice that poverty measured by the poverty gap at $\$ 3.1$ a negative impact on emissions of $\mathrm{CO} 2$ at a $10 \%$ threshold. That is to say, if measured by the poverty gap of $\$ 3.1$ poverty increases by ten units, then the CO2 emissions decrease to 0.197871 units. 
We find that the LIDE variable measuring foreign direct investment has a negative and significant impact on emissions of $\mathrm{CO} 2$ at a $10 \%$ threshold. That is to say, if the level of foreign direct investment increased by 10 units, while the emissions of $\mathrm{CO} 20.004131$ units.

The LCBEC variable that measures the market capitalization of listed companies is negative and statistically significant at a threshold of $1 \%$. So if the market capitalization of listed companies increased by one then, poverty measured by the GINI index decreases by 0.066272 units.

Is statistically significant and positive at a $1 \%$ level. nouThe variable measuring LCER the consumption of renewable energy also has a significant negative on $\mathrm{CO} 2$ emissions to a level of 5\%. That is to say, if the level of consumption of renewable energy increased by five units, while the $\mathrm{CO} 2$ emissions decrease to 0.254515 units.

We notice that the LDEP variable measuring government spending has a negative impact on emissions of $\mathrm{CO} 2$ at a $10 \%$ threshold. That is to say, if the level of public spending increases by ten units, then the $\mathrm{CO} 2$ emissions decrease to 0.161988 units.

So we notice that the LDF variable measuring financial development in a negative and significant impact on emissions of $\mathrm{CO} 2$ at a threshold of 5\%. That is to say, if the level of financial development increases five units, while the $\mathrm{CO} 2$ emissions decrease to 0.124330 units.

Is statistically significant and positive at a $1 \%$ level. nouThe LFBC variable that measures the gross formation of capital stock also has a positive and significant impact on emissions of $\mathrm{CO} 2$ at a threshold of $1 \%$. That is to say, if the level of gross fixed capital stock increases by one, then the CO2 emissions increase of 0.013852 units.

The LPIB variable that measures the GDP growth rate is statistically significant and negative at the $1 \%$ level. So if the GDP growth rate increased by one then the $\mathrm{CO} 2$ emissions decrease to 0.006346 units.

Is statistically significant and positive at a $1 \%$ level. nouThe LPU variable that measures the urban population also has a positive and significant impact on emissions of $\mathrm{CO} 2$ at a threshold of $1 \%$. That is to say, if the level of the urban population increases by one, then the $\mathrm{CO} 2$ emissions increase by 3.064975 units.

We find that the LTAJ variable that measures the youth literacy rate has a positive impact on emissions of $\mathrm{CO} 2$ at a threshold of 5\%. That is to say, if the youth literacy rate increases five units, while the $\mathrm{CO} 2$ emissions increase of 0.293943 units.

Finally, the LUE variable which measures the level of energy consumption is statistically significant and negative at a threshold of $5 \%$. So, if power consumption increases five units then the $\mathrm{CO} 2$ emissions decrease to 0.451683 units.

Table 15. Estimated FMOLS for variable LCO2

\begin{tabular}{|c|c|c|c|c|}
\hline Variable & Coefficient & Std. error & Does Statistic & Prob. \\
\hline LGINI & 0.858714 & 0.266085 & $3.227214 *$ & 0.0061 \\
\hline \$ LPOV1_91 & 0.004099 & 0.065424 & 0.062650 & 0.9509 \\
\hline \$ LPOV3_1 & -0.197871 & 0.109206 & $-1.811900 * * *$ & 0.0915 \\
\hline LIDE & -0.004131 & 0.002088 & $-1.977926 * * *$ & 0.0680 \\
\hline LCBEC & -0.005649 & 0.021867 & -0.258355 & 0.7999 \\
\hline LCER & -0.254515 & 0.108392 & $-2.348089 * *$ & 0.0341 \\
\hline CHL & 0.010985 & 0.048753 & 0.225315 & 0.8250 \\
\hline LDEP & -0.161988 & 0.086178 & $-1.879687 * * *$ & 0.0811 \\
\hline LDF & -0.124330 & 0.057822 & $-2.150243 * *$ & 0.0495 \\
\hline LFBC & 0.013852 & 0.002315 & $5.983665 *$ & 0.0000 \\
\hline LINF & 0.005952 & 0.003570 & 1.667186 & 0.1177 \\
\hline LPIB & -0.006346 & 0.001542 & $-4.115193 *$ & 0.0011 \\
\hline LPU & 3.064975 & 0.172420 & $17.77623 *$ & 0.0000 \\
\hline LTAJ & 0.293943 & 0.102428 & $2.869763 * *$ & 0.0124 \\
\hline LUE & -0.451683 & 0.162992 & $-2.771202 * *$ & 0.0150 \\
\hline $\mathrm{C}$ & -3.514484 & 1.976048 & $-1.778542 * * *$ & 0.0970 \\
\hline R-squared & 0.994703 & \multicolumn{2}{|c|}{ Mean dependent var } & 9.856607 \\
\hline Adjusted R-squared & 0.989028 & \multicolumn{2}{|c|}{ SD dependent var } & 0.261337 \\
\hline
\end{tabular}

Note: $(*)(* *)$ and $(* * *)$ are significant values for the $1 \%, 5 \%$ and $10 \%$ respectively 


\subsection{The Causality Test}

We need to check whether the IDE cause poverty and sustainable development or poverty and sustainable development are causing FDI in Tunisia.

Acceptance or rejection of the null hypothesis of Granger causality test is based on a threshold of 5\%. If the probability of the test is less than $5 \%$ in this case we reject the null hypothesis and if the probability is greater than $5 \%$ then we accept the null hypothesis of no causality.

Tables 16, 17, 18 and 19 summarize all the results of causality test for the three indicators of poverty and sustainable development in the case of Tunisia and for the study period of 1985 to 2015.

According to Table 16, we noticed that there is a unidirectional relationship between financial development and poverty as measured by the GINI index Granger. Only the GINI index can cause Granger financial development.

Thus, we noticed that there is a unidirectional relationship between Youth literacy rateand poverty measured by the Gini index Granger. Alone, Youth literacy rate can cause Granger poverty as measured by the GINI index.

Thus there is no causal relationship between the Gini index and other senses to control variables Granger as their probability values are greater than 0.05 , which allow accepting the null hypothesis of the test.

Table 16. The causality test for the variable LGINI

\begin{tabular}{llll}
\hline Null Hypothesis: & Obs & F-Statistic & Prob. \\
\hline \$ POV1_91 does not Granger Cause GINI & 29 & 1.78857 & 0.1888 \\
GINI does not Granger Cause \$ POV1_91 & & 0.40226 & 0.6732 \\
\$ POV3_1 does not Granger Cause GINI & 29 & 1.93906 & 0.1657 \\
GINI does not Granger Cause \$ POV3_1 & & 0.73445 & 0.4902 \\
FDI does not Granger Cause GINI & 29 & 0.09735 & 0.9076 \\
GINI does not Granger Cause IDE & & 2.48703 & 0.1043 \\
CBEC does not Granger Cause GINI & 29 & 0.76062 & 0.4783 \\
GINI does not Granger Cause CBEC & & 0.47577 & 0.6271 \\
REC does not Granger Cause GINI & 29 & 0.50645 & 0.6089 \\
GINI does not Granger Cause CER & & 2.24421 & 0.1278 \\
CH does not Granger Cause Gini & 29 & 0.45427 & 0.6403 \\
Gini does not Granger Cause CH & & 1.86453 & 0.1767 \\
DEP does not Granger Cause GINI & 29 & 0.22867 & 0.7973 \\
GINI does not Granger Cause DEP & & 2.90217 & 0.0743 \\
DF does not Granger Cause GINI & 29 & 1.33714 & 0.2815 \\
GINI does not Granger Cause DF & & 10.9568 & 0.0004 \\
BCF does not Granger Cause GINI & 29 & 3.30681 & 0.0539 \\
GINI does not Granger Cause FBC & & 0.46387 & 0.6344 \\
INF does not Granger Cause GINI & 29 & 0.00827 & 0.9918 \\
GINI does not Granger Cause INF & & 1.57392 & 0.2279 \\
GDP does not Granger Cause GINI & 29 & 0.21173 & 0.8107 \\
GINI does not Granger Cause GDP & & 1.06202 & 0.3615 \\
PU does not Granger Cause GINI & 29 & 0.52777 & 0.5966 \\
GINI does not Granger Cause PU & & 0.20606 & 0.8152 \\
TAJ does not Granger Cause GINI & 29 & 10.2676 & 0.0006 \\
GINI does not Granger Cause TAJ & & 0.18175 & 0.8349 \\
EU does not Granger Cause GINI & 29 & 2.61823 & 0.0936 \\
GINI does not Granger Cause EU & & 1.30606 & 0.2895 \\
\hline
\end{tabular}

According to Table 17, we find that there is a unidirectional relationship between financial development and poverty measured by the gap of $\$ 1.91$ Granger. Only poverty measured by the gap of $\$ 1.91$ may result Granger financial development.

Thus, we notice that there is no causal relationship between poverty gap to $\$ 1.91$ and the other control variables Granger as their probability values are greater than 0.05 , which allow to accept the null hypothesis of the test. 
Table 17. The causality test for the variable \$ LPOV1_91

\begin{tabular}{|c|c|c|c|}
\hline Null Hypothesis: & Obs & F-Statistic & Prob. \\
\hline \$ POV3_1 does not Granger Cause \$ POV1_91 & 29 & 0.28438 & 0.7550 \\
\hline \$ POV1_91 does not Granger Cause \$ POV3_1 & & 0.65328 & 0.5293 \\
\hline FDI does not Granger Cause \$ POV1_91 & 29 & 0.43247 & 0.6539 \\
\hline \$ POV1_91 does not Granger Cause IDE & & 0.68854 & 0.5120 \\
\hline CBEC does not Granger Cause \$ POV1_91 & 29 & 2.58075 & 0.0966 \\
\hline \$POV1_91 does not Granger Cause CBEC & & 0.44732 & 0.6446 \\
\hline REC does not Granger Cause \$ POV1_91 & 29 & 1.18065 & 0.3243 \\
\hline \$ POV1_91 does not Granger Cause CER & & 1.50784 & 0.2416 \\
\hline CH does not Granger Cause \$ POV1_91 & 29 & 0.07252 & 0.9302 \\
\hline \$ POV1_91 does not Granger Cause CH & & 2.98879 & 0.0693 \\
\hline DEP does not Granger Cause \$ POV1_91 & 29 & 0.95020 & 0.4007 \\
\hline \$ POV1_91 does not Granger Cause DEP & & 3.05587 & 0.0657 \\
\hline DF does not Granger Cause \$ POV1_91 & 29 & 0.66077 & 0.5256 \\
\hline \$ POV1_91 does not Granger Cause DF & & 3.61592 & 0.0424 \\
\hline BCF does not Granger Cause \$ POV1_91 & 29 & 0.56296 & 0.5769 \\
\hline \$ POV1_91 does not Granger Cause FBC & & 1.26375 & 0.3007 \\
\hline INF does not Granger Cause \$ POV1_91 & 29 & 0.83133 & 0.4476 \\
\hline \$ POV1_91 does not Granger Cause INF & & 0.25129 & 0.7798 \\
\hline GDP does not Granger Cause \$ POV1_91 & 29 & 0.51883 & 0.6017 \\
\hline \$ POV1_91 does not Granger Cause GDP & & 0.70851 & 0.5024 \\
\hline PU does not Granger Cause \$ POV1_91 & 29 & 1.40620 & 0.2646 \\
\hline \$ POV1_91 does not Granger Cause PU & & 0.31693 & 0.7314 \\
\hline TAJ does not Granger Cause \$ POV1_91 & 29 & 1.77409 & 0.1912 \\
\hline \$ POV1_91 does not Granger Cause TAJ & & 3.26023 & 0.0559 \\
\hline EU does not Granger Cause \$ POV1_91 & 29 & 1.33399 & 0.2823 \\
\hline \$ POV1_91 does not Granger Cause EU & & 3.28716 & 0.0547 \\
\hline
\end{tabular}

According to Table 18, we found that there is a one way relationship public spending and poverty measured by the gap of \$3.1 Granger. Only poverty measured by the gap of \$ 3.1 can cause Grangerpublic spending.

Indeed, we find that there is a unidirectional relationship between financial development and poverty measured by the gap of \$ 3.1 Granger. Only poverty measured by the gap of $\$ 3.1$ can cause Granger financial development.

In addition, we notice that there is no causal relationship between poverty gap of $\$ 3.1$ and other senses to control variables Granger as their probability values are above 0.05 that allow for accept the null hypothesis of the test.

Table 18. The causality test for the variable \$ LPOV3_1

\begin{tabular}{llll}
\hline Null Hypothesis: & Obs & F-Statistic & Prob. \\
\hline FDI does not Granger Cause \$ POV3_1 & 29 & 0.40704 & 0.6701 \\
\$ POV3_1 does not Granger Cause IDE & & 1.23256 & 0.3093 \\
CBEC does not Granger Cause \$ POV3_1 & 29 & 2.48471 & 0.1045 \\
\$ POV3_1 does not Granger Cause CBEC & & 0.56804 & 0.5741 \\
REC does not Granger Cause \$ POV3_1 & 29 & 1.90440 & 0.1707 \\
\$ POV3_1 does not Granger Cause CER & & 1.87210 & 0.1756 \\
CH does not Granger Cause \$ POV3_1 & 29 & 0.16932 & 0.8452 \\
\$ POV3_1 does not Granger Cause CH & & 2.75550 & 0.0837 \\
\hline
\end{tabular}




\begin{tabular}{lccc}
\hline DEP does not Granger Cause \$ POV3_1 & 29 & 0.87438 & 0.4300 \\
\$ POV3_1 does not Granger Cause DEP & & 3.96075 & 0.0326 \\
DF does not Granger Cause \$ POV3_1 & 29 & 0.96038 & 0.3970 \\
\$ POV3_1 does not Granger Cause DF & & 4.70243 & 0.0189 \\
BCF does not Granger Cause \$ POV3_1 & 29 & 0.72348 & 0.4953 \\
\$ POV3_1 does not Granger Cause FBC & & 1.12460 & 0.3413 \\
INF does not Granger Cause \$ POV3_1 & 29 & 0.51308 & 0.6051 \\
\$ POV3_1 does not Granger Cause INF & & 0.35630 & 0.7039 \\
GDP does not Granger Cause \$ POV3_1 & 29 & 0.48649 & 0.6207 \\
\$ POV3_1 does not Granger Cause GDP & & 1.06178 & 0.3615 \\
PU does not Granger Cause \$ POV3_1 & 29 & 1.07621 & 0.3568 \\
\$ POV3_1 does not Granger Cause PU & & 0.24035 & 0.7882 \\
TAJ does not Granger Cause \$ POV3_1 & 29 & 4.77267 & 0.0180 \\
\$ POV3_1 does not Granger Cause TAJ & & 2.11493 & 0.1426 \\
EU does not Granger Cause \$ POV3_1 & 29 & 2.26339 & 0.1257 \\
\$ POV3_1 does not Granger Cause EU & & 2.74453 & 0.0845 \\
\hline
\end{tabular}

According to Table 19, we found that there is a unidirectional relationship between the $\mathrm{CO} 2$ emissions and the unemployment rate Granger. Only the $\mathrm{CO} 2$ emissions can cause Granger unemployment rate.

Indeed, we found that there is a bidirectional relationship between financial development and emissions $\mathrm{CO} 2$ Granger. That is to say, financial development can cause Granger's CO2 emissions. Thus, $\mathrm{CO} 2$ emissions can cause Granger financial development.

In addition, we found that there is a unidirectional Granger relationship between the $\mathrm{CO} 2$ emissions and gross fixed capital stock. Alone, gross fixed capital stock can cause Granger the $\mathrm{CO} 2$ emissions.

Also, there is a one-way Granger relationship the $\mathrm{CO} 2$ emissions and GDP growth rate. Alone, GDP growth rate can cause Granger the $\mathrm{CO} 2$ emissions.

Finally, there is a one-way Granger relationship the $\mathrm{CO} 2$ emissions and consumption of energy. Only, the $\mathrm{CO} 2$ emissions can cause Granger consumption of energy in Tunisia.

In addition, we noticed that there is no causal relationship between $\mathrm{CO} 2$ emissions and other controls Granger as their probability values are above 0.05 that allow accepting the null hypothesis testing.

Table 19. The causality test for variable LCO2

\begin{tabular}{llll}
\hline Null Hypothesis: & Obs & F-Statistic & Prob. \\
\hline GINI does not Granger Cause CO2 & 29 & 1.83509 & 0.1813 \\
CO2 does not Granger Cause GINI & & 1.52076 & 0.2389 \\
\$ POV1_91 does not Granger Cause CO2 & 29 & 1.95086 & 0.1640 \\
CO2 does not Granger Cause \$ POV1_91 & & 2.73310 & 0.0852 \\
\$ POV3_1 does not Granger Cause CO2 & 29 & 1.85578 & 0.1781 \\
CO2 does not Granger Cause \$ POV3_1 & & 2.11863 & 0.1421 \\
FDI does not Granger Cause CO2 & 29 & 0.14936 & 0.8621 \\
CO2 does not Granger Cause IDE & & 0.74571 & 0.4851 \\
CBEC does not Granger Cause CO2 & 29 & 2.97077 & 0.0703 \\
CO2 does not Granger Cause CBEC & & 0.71160 & 0.5009 \\
REC does not Granger Cause CO2 & 29 & 2.00474 & 0.1566 \\
CO2 does not Granger Cause CER & & 1.21854 & 0.3133 \\
CH does not cause CO2 Granger & 29 & 0.26080 & 0.7726 \\
CO2 does not Granger Cause CH & & 3.48696 & 0.0468 \\
DEP does not Granger Cause CO2 & 29 & 2.13335 & 0.1404 \\
CO2 does not Granger Cause DEP & & 1.87776 & 0.1747 \\
DF does not Granger Cause CO2 & 29 & 7.58332 & 0.0028 \\
CO2 does not Granger Cause DF & & 5.01786 & 0.0151 \\
BCF does not Granger Cause CO2 & 29 & 5.79483 & 0.0088 \\
CO2 does not Granger Cause FBC & & 1.13413 & 0.3383 \\
\hline
\end{tabular}




\begin{tabular}{lccc}
\hline INF does not Granger Cause CO2 & 29 & 0.41445 & 0.6653 \\
CO2 does not Granger Cause INF & & 1.29838 & 0.2915 \\
GDP does not Granger Cause CO2 & 29 & 8.60552 & 0.0015 \\
CO2 does not Granger Cause GDP & & 0.06454 & 0.9377 \\
PU does not Granger Cause CO2 & 29 & 2.37618 & 0.1144 \\
CO2 does not Granger Cause PU & & 1.08033 & 0.3554 \\
TAJ does not Granger Cause CO2 & 29 & 0.38528 & 0.6844 \\
CO2 does not Granger Cause TAJ & & 1.94212 & 0.1653 \\
EU does not Granger Cause CO2 & 29 & 1.21015 & 0.3157 \\
CO2 does not Granger Cause EU & & 3.81543 & 0.0364 \\
\hline
\end{tabular}

\section{Conclusion}

Our goal in this paper is the study of the impact of FDI on poverty and sustainable development in the case of Tunisia and during the study period from 1985 to 2015. In addition, the results showed that all the correlation coefficients between the explanatory variables do not exceed the tolerance limit $(0.7)$, which does not cause problems when the estimation of the model. That is to say, we can integrate the different variables used in the same model.

Then we originated the presentation and analysis of the unit root test of co-integration test and error correction model. In the case of Tunisia, we found that only LIDE variables LPIB, LFBC and CHL are non-stationary in level according to the test Augmented Dickey-Fuller but all variables are stationary in first difference according to this test. Thereafter, first difference, all variables are stationary according to the unit root test used. So, all variables are integrated of order 1 . Thus, we can use the cointegration test.

Indeed, the results of the null hypothesis test of no cointegration were rejected at the 5\% threshold, which explains the presence of a cointegration relationship between FDI, sustainable development and poverty. Finally, we present and interpreted the results of the estimated FMOLS model and Granger causality test to study the contribution of FDI to the poverty reduction and sustainable development in Tunisia.

We find that the LIDE variable measuring foreign direct investment has a significant negative impact on the Gini index to a threshold of $1 \%$. We notice the $\mathrm{LCO} 2$ variable that measures the $\mathrm{CO} 2$ emissions has a negative and significant impact on poverty as measured by the poverty gap at $\$ 1.91$ a threshold of $1 \%$.

We find the LGINI variable measuring poverty has a positive impact on emissions of $\mathrm{CO} 2$ at a threshold of $1 \%$. We notice that poverty measured by the poverty gap at $\$ 3.1$ a negative impact on emissions of $\mathrm{CO} 2$ at a $10 \%$ threshold. We prove that the LIDE variable measuring foreign direct investment has a negative and significant impact on emissions of $\mathrm{CO} 2$ at a $10 \%$ threshold. We find that the LIDE variable measuring foreign direct investment has a negative and significant impact on poverty as measured by the poverty gap at $\$ 3.1$ with a $5 \%$ threshold.

\section{References}

Abor, J., \& Harvey, S. K. (2008). Foreign direct investment and employment: host country experience. Macroeconomic and Finance in Emerging Market Economies, 1(2), 213-225. https://doi.org/10.1080/17520840802323224

Akinmulegun, S. O. (2012). Foreign Direct Investment and Standard of Living in Nigeria. Journal of Applied Finance \& Banking. London, 2, 295-309.

Balasubramanyam, V. N., Salisu, M., \& Sapsford, D. (1996). Foreign direct investment and growth in EP and IS countries. Economic Journal, 106, 92-105. https://doi.org/10.2307/2234933

Beck, T., Demirguç-Kunt, A., Levine, R., 2000. A new database on financial development and structure. World Bank Economic Review, 14, 597-605. https://doi.org/10.1093/wber/14.3.597

Borensztein, E., De Gregorio, J., \& Lee, J. W. (1998). How does foreign direct investment affect economic growth? Journal of International Economics, 45, 115-135. https://doi.org/10.1016/S0022-1996(97)00033-0

Fauzel, S., Seetanah, B., \& Sannassee, R. V. (2015). Foreign direct investment and welfare nexus in Sub-Saharan Africa. The Journal of Development Areas, 49, 271-283. https://doi.org/10.1353/jda.2015.0133

Fowowe, B., \& Shuaibu, M. I. (2014). Is Foreign Direct Investment Good for the Poor? New Evidence from African Countries. Economic Change and Restructuring, 47(4), 321-339. https://doi.org/10.1007/s10644- 
014-9152-4

Gohou, G., \& Soumaré, I. (2009). Impact of FDI on Poverty Reduction in Africa: Are There Regional Differences? Working Paper, African Development Bank.

Gohou, G., \& Soumaré, I. (2012). Does foreign direct investment reduce poverty in Africa and are there regional differences? World Development, 40, 75-95. https://doi.org/10.1016/j.worlddev.2011.05.014

Israel A.O. (2014). Impact of foreign direct investment on poverty reduction in Nigeria. Journal of Economics and Sustainable Development, 5(20).

King, R. G., \& Levine, R. (1993). Finance and growth: Schumpeter might be right. QuarterlyJournal of Economics, 108, 717-738. https://doi.org/10.2307/2118406

Levine, R., Loayza, N., \& Beck, T. (2000). Financial intermediation and growth: Causality and causes. Journal of Monetary Economics, 46, 31-77. https://doi.org/10.1016/S0304-3932(00)00017-9

Mpanju, A. K. (2012). The Impact of Foreign Direct Investment on Employment Creation in Tanzania, 2(1), January 2012.

Ogunniyi, M. B., \& Igberi, C. O. (2014). The Impact of Foreign Direct Investment [FDI] on Poverty Reduction in Nigeria. Journal of Economics and Sustainable Development, 5(14), 73-83.

Soumare I. (2015). Does Foreign Direct Investment Improve Welfare in North Africa? Africa Development Bank.

Umoh, O. J., Jacob, A. O., \& Chuku, C. A. (2012). Foreign Direct Investment and Economic Growth in Nigeria: An Analysis of the Endogenous Effects. Current Research Journal of Economic Theory, 4(3), 53-66.

\section{Copyrights}

Copyright for this article is retained by the author(s), with first publication rights granted to the journal.

This is an open-access article distributed under the terms and conditions of the Creative Commons Attribution license (http://creativecommons.org/licenses/by/4.0/). 